\title{
Doświadczenie migracji we współczesnej prozie słowackiej (na przykładzie tekstów Zuski Kepplovej)
}

\author{
Abstract \\ Migration Experiences in Contemporary Slovak Fiction (An Analysis \\ of Zuska Kepplová's Writing)
}

The article explores the problem of migration prose in Slovak literature and focuses on some aspects of Zuska Kepplová's books: Buchty švabachom (Buns in the Schwabacher) and $57 \mathrm{~km}$ od Taškentu (57 km from Tashkent). Some characters of Kepplová's debut prose, young immigrants from Central Europe living in their new countries, although realising their inferior status of "the Other", attempt to take adaptive actions and get closer to local culture, while others, on the contrary, close up in the enclave of migrants, refusing to confront the new situation. The majority of the protagonists live in a state of limbo and indeterminacy, and their identity can be described as a hybrid identity. The problem of cultural, social and mental boundaries is also present in Kepplová's prose, exemplified by the characters of expats from the West migrating to the post-comunist countries. The concept of hybridity is also reflected in the fragmentary and mosaic composition of the texts, the variety of literary forms and conventions applied.

Keywords: Slovak prose, Zuska Kepplová, migration, identity, hybridity.

Słowa kluczowe: proza słowacka, Zuska Kepplová, migracja, tożsamość, hybrydyzacja.

W literaturze słowackiej początku XXI wieku jedną z ważnych linii rozwojowych tworzą teksty, które tematyzują współczesne doświadczenie migracji i problemy związane z funkcjonowaniem w innym niż rodzime środowisku kulturowym. Do zagadnień, którym słowaccy twórcy poświęcają uwagę, należą przede wszystkim: konfrontacja wyobrażeń i obietnic o nieograniczonych możliwościach, jakie stały się udziałem mieszkańców Europy Środkowej dzięki otwarciu granic, z sytuacjami, które potwierdzają trwałość podziałów, przede wszystkim ekonomicznych i społecznych; wpływ sytuacji przemieszczenia na relacje rodzinne i kształt związków intymnych; sposoby radzenia sobie z poczuciem obcości i kompleksa- 
mi niższości w nowym otoczeniu; mechanizmy konstruowania obrazów rzeczywistości postkomunistycznej i jej wartościowania przez przybyszów z „lepszej”, „bardziej cywilizowanej” części świata. Zmiana miejsca pobytu, spotkanie z odmienną kulturą i konieczność sprostania określonym warunkom życia stanowią dla bohaterów wyzwanie, które wiąże się, oczywiście, nie tylko z praktycznymi aspektami bytowymi, ale także z koniecznością podjęcia pewnego wysiłku autoidentyfikacyjnego. Doświadczenie mobilności zawsze tego typu procesy prowokuje, jak stwierdza Ryszard Nycz:

Jeśli się zgodzić, że tożsamość jednostek i wspólnot kształtuje się w ścisłym związku ze środowiskiem, w którym toczy się ludzkie życie, to zmiana owego środowiska aktywować musi też prace tożsamościowe, choćby minimalnie redefiniujące dotychczasowy profil tej tożsamości ${ }^{1}$.

Na istotne miejsce, jakie we współczesnych utworach słowackich zajmują kwestie dotyczące migracji, zwracają uwagę autorzy poświęconej prozie części pracy zbiorowej Hladanie súčasnosti. Slovenská literatúra začiatku 21. storočia, Karol Csiba, Ivana Taranenková i Radoslav Passia. W tej, jedynej do dzisiaj książkowo opublikowanej, próbie syntezy rozwoju literatury słowackiej na początku trzeciego tysiąclecia rozdział dotyczący sposobów podejmowania zagadnień tożsamości w najnowszej prozie obejmuje omówienie, obok nurtu autobiograficznego, pisarstwa feministycznego, regionalizmu i „lokalizmu”, interesującą nas linię. Autorzy ogólnie charakteryzują ją jako prozę, w której „problem tożsamości i jej kryzysu przedstawiany jest poprzez konfrontację człowieka z «wielkim», najczęściej europejskim światem" ", wskazują na dużą frekwencję tematów izolacji i wykluczenia społecznego, które łączone są z motywem kraju i domu rodzinnego, a wśród głównych przedstawicielek wymieniają autorki z generacji urodzonej w latach 70. i 80. XX wieku: Svetlanę Žuchovą, Ivanę Dobrakovovą, Zuskę Kepplovą, Michaelę Rosovą, Márię Modrovich. Zaproponowane w opracowaniu określenie porządkujące expatovská próza można uznać za dyskusyjne, przede wszystkim ze względu na zawartość semantyczną słowa ekspat / ekspata, które zarówno w języku słowackim, jak i polskim oznacza przede wszystkim wysokiej klasy specjalistę, który podejmuje pracę za granicą, zwykle w oddziale międzynarodowej korporacji, motywowany perspektywą wysokich zarobków. Biorąc pod uwagę sytuację bohaterów omawianego nurtu prozy, w większości migrantów ekonomicznych lub studentów, a w zdecydowanej mniejszości ekspatów w przywołanym sensie (tę grupę w tekstach reprezentują przybysze do Europy Środkowej z Zachodu), można się domyślać, że autorzy publikacji we wprowadzonym terminie eksponują głównie etymologiczny związek $\mathrm{z}$ łacińskim expatriare, oznaczającym „opuszczać ojczyznę”, oraz podkreślają kwestię możliwości przemieszczania się i dobrowolności wyjazdu w nowych warunkach polityczno-społecznych, tym samym zaznaczając wyraźne odróżnienie od litera-

1 R. Nycz, Kultura jako czasownik. Sondowanie nowej humanistyki, Warszawa 2017, s. 117.

2 K. Csiba, R. Passia, I. Taranenková, Próza [w:] Hladanie súčasnosti. Slovenská literatúra začiatku 21. storočia, red. R. Passia, I. Taranenková, Bratislava 2014, s. 60. Cytaty z tekstów słowackich przytaczam we własnym tłumaczeniu. 
tury emigracyjnej, z charakterystycznymi dla niej kontekstami funkcjonowania i głównymi kręgami tematycznymi. Trudno przewidzieć, czy zaproponowana nazwa ustabilizuje się w słowackim literaturoznawstwie, natomiast dla porządku warto dodać, że formułowane wcześniej, w pracach poświęconych konkretnym tekstom, sugestie, zgodnie z którymi sytuację literackich migrantów można ująć za pomocą metaforycznej kategorii współczesnego nomadyzmu, szybko zostały poddane krytyce ${ }^{3}$. Dla terminologicznych rozstrzygnięć zapewne konieczny jest większy dystans czasowy, dlatego proponuję pozostawić na marginesie rozważań kwestię samej nazwy nurtu i zastanowić się nad możliwymi kontekstami interpretacyjnymi konkretnych słowackich tekstów. Cenną inspirację w tym zakresie stanowić mogą propozycje opisu literatury tematyzującej współczesne zjawisko mobilności oraz pewne postulaty badawcze sformułowane na gruncie polskiej wiedzy o literaturze.

Przemysław Czapliński w otwierającym tom Poetyka migracji. Doświadczenie granic w literaturze polskiej przełomu XX i XXI wieku tekście Kontury mobilności pojęciu ,poetyka migracji” przypisuje trzy, jak podkreśla, eksperymentalne i poszukiwawcze, znaczenia. W pierwszym rozumieniu chodzi o

zbiór elementów i ich kombinacji swoistych dla pewnego korpusu dzieł. Byłoby to określenie bliskie pojęciom „nurt”, „konwencja” czy „praktyka artystyczna”, odniesionych do piśmiennictwa, które w swoim centrum stawia ruch i związane z nim rozmaite doświadczanie granic. Literatura, która owe doświadczenia ruchu i granicy artykułuje, rozluźnia dotychczasowe umiejscowienia, ale wchodzi w nowe relacje - dwunarodowe, międzynarodowe, kontynentalne czy światowe ${ }^{4}$.

Drugie znaczenie związane jest z perspektywą badań transdycyplinarnych, która pozwala na materiale literackim uchwycić proces przechodzenia kultury emigracyjnej $\mathrm{w}$ kulturę migrantów, trzecie natomiast eksponuje autokreacyjny charakter samej migracji, związany z koniecznością tworzenia tożsamości, zarówno zbiorowej, jak i jednostkowej ${ }^{5}$. Dla naszych rozważań szczególnie istotne są uwagi związane z pierwszym z wyróżnionych znaczeń, dodajmy, że odnieść je można do będącego obiektem naszego zainteresowania nurtu prozy słowackiej, więc być może warto zastanowić się nad wykorzystaniem w jego opisie właśnie pojęcia ,poetyka migracji” zamiast proponowanej przez słowackich badaczy nazwy. Ważne w ustaleniach Czaplińskiego jest również dostosowane do literaturoznawczych potrzeb pojęcie hybrydyczności; autor wyjaśnia je na tle historycznych sposobów rozwiązywania dylematów artystycznych nowoczesności w taki sposób:

Rozumiem przez to strategię, która zachowuje przeciwieństwa, ale ich nie syntetyzuje. Zamiast awangardowego „albo - albo”, neoawangardowego „trans”, późna nowoczesność wybiera „,i - i”. A więc prawdziwe i zmyślone, jak w apokryfie; wysokie i niskie, jak w pastiszu; zaangażowane i estetyczne, jak w realizmie afektywnym. Rozwiązanie polega

3 V. Barborík, Ja: jedna (jediná?) podoba súčasnej prózy, „Romboid” 2012, nr 7, s. 53-54.

4 P. Czapliński, Kontury mobilności [w:] Poetyka migracji. Doświadczenie granic w literaturze polskiej przełomu XX i XXI wieku, red. P. Czapliński, R. Makarska, M. Tomczok, Katowice 2013, s. 40-41.

5 Ibid., s. 41-42. 
zatem na trwaniu w sprzecznościach - na odsłanianiu i zachowywaniu heterogeniczności bez poszukiwania skrajnych czy syntetyzujących form. (...) Literatura hybrydyczna pozostawia w stanie nierozstrzygniętym konflikt między alternatywnymi systemami wartości, eksponując moment ich spotkania ${ }^{6}$.

Pojęcie hybrydyczności można zastosować również do opisu specyfiki procesów tożsamościowych migrantów; kwestię tę omawia Czapliński w cytowanym tekście, uwagę poświęca jej także Hanna Gosk w artykule wstępnym innego ważnego tomu, Narracje migracyjne w literaturze polskiej XX $i$ XXI wieku. Badaczka charakteryzuje narrację migracyjną i jej podmiot następująco:

Próba znarratywizowania doświadczenia migracyjnego to próba stworzenia opowieści wielowarstwowej, hybrydycznej, jeśli idzie o tworzywo i sposoby jego ujmowania w języku. To narracja rozpięta między starym i nowym, znanym i nieznanym, swoim i obcym. Jej podmiot - w sytuacji, w której podejmuje opowieść - jest już podmiotem hybrydycznym, można by rzec, iż wieloimiennym. Tok jego opowieści, rozłożenie w niej akcentów tematycznych (np. przestrzennych) i emocjonalnych wiele mówi o przebiegu procesów adaptacyjnych w nowym miejscu. O ich sukcesie lub niepowodzeniu, o tworzeniu ,trzeciej jakości”, jaką stanowi permanentne niedostosowanie, pozostawanie jednocześnie „wewnątrz” i ,na zewnątrz” zarówno sfery „tam - wtedy”, jak i sfery „tutaj - teraz”. W narracji migracyjnej występują rozmaite niestałości i nieoczywistości. Zarówno podmiot, jak i przestrzenie, w których się on porusza, wykazują wieloimienność i wymagają podejścia anamorficznego, jeśli chcieć wyprowadzić z nich określony rys

Do proponowanych przez polskich badaczy ujęć zjawiska, których fragmenty zostały przywołane w celu stworzenia ogólnej, teoretycznej ramy rozważań, będę powracał w części interpretacyjnej tekstu.

Współczesną słowacką prozę dotyczącą migracji reprezentują, jak wyżej wspomniałem, przede wszystkim pisarki, zwykle posiadające doświadczenie pobytu za granicą, związanego ze studiami, sezonową lub stałą pracą, o czym mówią w wywiadach, swojej twórczości jednak nie traktują w kategoriach autobiografizmu. Zuska Kepplová, której tekstom poświęcone będą poniższe uwagi, debiutowała w 2011 roku książką Buchty švabachom (Buchty szwabacha), następnie ukazały się $57 \mathrm{~km}$ od Taškentu (57 km od Taszkentu, 2013) oraz Reflux. Niekto cudzí je v dome (Refluks. Ktoś obcy jest $w$ domu, 2015). Za centralne zagadnienie jej utworów można uznać problem granic, nie tylko geograficznych, ale przede wszystkim granic kulturowych, symbolicznych, mentalnych, intymnych, próby ich przekraczania bądź zacierania, stosunek do opozycji ja/inny, swoje/obce, narodowe/ponadnarodowe. Problematyka ta, związana z kwestiami tożsamościowymi, rozwijana jest zarówno w tekstach, których akcja usytuowana jest w obcej dla bohaterek i bohaterów przestrzeni, jak i, co widać w ostatniej opublikowanej książce, w środowisku rodzimym, więc przynajmniej teoretycznie - bezpiecznym i oswojonym, w którym jednak rozmaitego typu podziały czy praktyki wykluczenia również odgrywają ważną rolę. Poniższe propozycje interpretacyjne, głównie

6 Ibid., s. 27.

7 H. Gosk, Wprowadzenie [w:] Narracje migracyjne w literaturze polskiej XX i XXI wieku, red. H. Gosk, Kraków 2012, s. 8. 
ze względu na ograniczenia objętościowe artykułu, zostały przygotowane na podstawie materiału z dwóch pierwszych pozycji słowackiej autorki.

W debiucie i książce $57 \mathrm{~km}$ od Taškentu Kepplová zastosowała podobną strukturę; kompozycyjnemu podziałowi na dwie główne części odpowiada wyeksponowanie dwóch podstawowych linii problemowych, pierwsza związana jest $\mathrm{z}$ funkcjonowaniem jednostki w nowym otoczeniu, druga $-\mathrm{z}$ zagadnieniem relacji intymnych. Dla naszych rozważań istotna jest przede wszystkim pierwsza wyróżniona linia i jej poświęcimy uwagę, natomiast kwestie związane $\mathrm{z}$ drugim kręgiem tematycznym zostaną jedynie skrótowo przedstawione w kontekście ich związków z migracją.

W części pierwszej debiutu, Môžeš sa nebát' (Możesz się nie bać) ${ }^{8}$, znaczące i wprowadzające w temat konfrontacji jednostki i obcej lokalizacji są tytuły podrozdziałów, zbudowane $\mathrm{z}$ dwóch elementów: imienia bohaterki / bohatera i nazwy miasta, europejskiej metropolii, w której rozgrywa się akcja. Bohaterowie to przede wszystkim Słowaczki i Słowacy, ale także Czesi, Polacy, Węgrzy, czyli przedstawiciele Europy Środkowej, dla której literackich reprezentacji, przypomnijmy za Aleksandrem Fiutem, zagadnienia nieakceptowanej peryferyjności i problematycznej tożsamości są jednymi z najważniejszych ${ }^{9}$. Ich doświadczenia związane z przemieszczeniem przedstawione są fragmentarycznie, sposób odczuwania i rozumienia sytuacji, w jakiej się znajdują, poznajemy przede wszystkim na podstawie opisów konkretnych wydarzeń, podejmowanych działań, reakcji emocjonalnych lub psychosomatycznych, dialogów, komentarzy. Elementy te budują skomplikowany, przypominający mozaikę, obraz kondycji współczesnego migranta, podejmującego decyzję o zmianie miejsca zamieszkania z powodu pracy lub nauki, motywowanego teoretycznie nieograniczonymi możliwościami samorealizacji.

Chociaż w tekście brakuje wątków związanych z tak zwaną wyobraźnią przedmigracyjną, zespołem wyobrażeń dotyczących życia po opuszczeniu kraju rodzinnego, założyć można, że związane one były z uczuciami nadziei i perspektywami polepszenia własnej sytuacji. O ile jednak przekroczenie granicy geograficznej nie wymaga od bohaterów właściwie żadnego wysiłku, o tyle granice innego typu - społeczne, kulturowe, mentalne - wydają się zdecydowanie trudniejsze do przekroczenia, bohaterom ciąży ,brzemię obcości kulturowej i niższości materialnej" ${ }^{10}$ ograniczające ich działania. Konfrontacja z nową rzeczywistością zmusza do szybkiej weryfikacji oczekiwań i właściwie w utworze mamy głównie opisane rezultaty tej weryfikacji - smutek, poczucie samotności i braku

8 We fragmentach poświęconych pierwszej części debiutu Kepplovej nawiązuję do niektórych wątków przygotowanego na konferencję K poetologickým a axiologickým aspektom slovenskej literatúry po roku 2000 V (Preszów 2017) referatu K otázke (ne)možnosti prekročenia hraníc v próze Zusky Kepplovej.

9 A. Fiut, Być (albo nie być) Środkowoeuropejczykiem, Kraków 1999, s. 24-25. Na płaszczyźnie ogólnej współczesne teksty poświęcone migracji można rozpatrywać w kontekście pytań o tożsamość środkowoeuropejską, chociaż wyróżnione przez Fiuta problemy (nieakceptowana peryferyjność, poczucie ruchomości granic, tożsamość problematyczna) w najnowszej literaturze prezentowane są w inny sposób niż w utworach, którym uwagę badacz poświęca w przywoływanej pracy.

10 Z. Pruškovā, Stratení v príbehoch, vynájdení v jazyku, ,Romboid” 2011, nr 9-10-11, s. 13. 
zakorzenienia; jak komentuje to Radoslav Passia: „Świat, na pierwszy rzut oka kuszący i otwarty, dla literackich postaci Kepplovej staje się nie tylko źródłem większej lub mniejszej nostalgii za krajem rodzinnym (...), ale także źródłem trudnej do przezwyciężenia frustracji"'11.

Przyjmowane w nowym otoczeniu postawy migrantów można opisać, wskazując pewne charakterystyczne strategie działania i sposoby rozumienia aktualnej sytuacji oraz możliwych perspektyw jej zmiany. Dla części bohaterek celem jest asymilacyjny sukces i, chociaż zdają sobie sprawę z własnej pozycji „obcego”, są świadome istniejących uprzedzeń i barier, nie pozostają bierne, mają konkretne plany, które próbują realizować. Trudna sytuacja, w jakiej się znajdują, wyznaczana niesatysfakcjonującą pracą, zatłoczonym mieszkaniem z przypadkowymi ludźmi, brakiem intymności, zmęczeniem, poczuciem niższej wartości społecznej, jest traktowana jako etap przejściowy, który w projektowanej, stabilnej i bezpiecznej przyszłości może być ewentualnie tematem lekkich anegdot, natomiast dla kształtu tożsamości jest zdecydowanie niepożądany. Podejmują konkretne działania, żeby etap ten jak najszybciej zamknąć, odciąć się od przestrzeni, w których jedynym wyznacznikiem wartości człowieka jest zgoda na wykonywanie ciężkiej pracy, zapomnieć o podrzędnej roli, z którą nie chcą się identyfikować. Stąd wynika niechęć do podtrzymywania kontaktu z osobami spotkanymi w początkowym okresie, nawet mimo odczuwanej do nich sympatii. Swoją potrzebę odrębności, niechęć do wtopienia się w grupę ekonomicznych migrantów zaznaczają drobnymi gestami, mającymi głównie znaczenie symboliczne, związane z wyobrażeniem adaptacji - zamiast w popularnym wśród migrantów Tesco robią zakupy w lepszym sklepie, wyrabiają kartę na metro, rezygnując z przejazdów darmowymi autobusami, pozwalają sobie na małe przyjemności, jak kawa w muzeum.

W propozycji opisu migracji jako wyzwania i czynnika tożsamościotwórczego Hanna Gosk wyróżnia trzy podstawowe reakcje jednostki na nową sytuację:

Może „otworzyć” podmiot na nowe doznania, zainspirować go do działań kreacyjnych, może też „zamknąć” go w przestrzeni wyobrażonej i czasie przeszłym („tam - wtedy”), uniemożliwiając kontakt $\mathrm{z}$ nowym otoczeniem albo... pozostawić w stanie zawieszenia i niedookreślenia (,pomiędzy”) ${ }^{12}$.

Omawiane bohaterki Kepplovej, chociaż przyjmują perspektywę adaptacyjną, a ich wysiłki przynoszą konkretne rezultaty - podejmują studia, z czasem otrzymują stosunkowo dobrą, satysfakcjonującą pracę, pozostają jednak właśnie we wskazanym przez Gosk stanie ,pomiędzy”, poczucie niepełnej przynależności, chociaż z czasem może słabnąć, wydaje się już na stałe wpisane w ich psychikę. Poczucie obcości może się manifestować podświadomie, w snach lękowych, uczuciu braku powietrza, będącym refleksem dusznych, przepełnionych pokojów emigrantów, można starać się je w sposób ironiczny oswoić, jak robi to jedna z postaci, tatuując sobie na brzuchu napis BUCHTY, swoisty znak przynależności do innej kultury. Istotne jest, że owa obcość może stać się zupełnie nieznacząca

11 R. Passia, Skúsenost's iným, „Romboid” 2011, nr 9-10-11, s. 14.

12 H. Gosk, op. cit., s. 8. 
lub niewidoczna, zwłaszcza w wielokulturowym środowisku, chodzi tutaj więc raczej o subiektywne, trudne do przezwyciężenia, mające źródła we wcześniejszych doświadczeniach, rozumienie własnej pozycji.

W przeciwieństwie do bohaterek dążących do uzyskania stabilności w nowej kulturze, część migrantów procesami integracyjnymi zupełnie nie jest zainteresowana, ich tożsamość związana jest $\mathrm{z}$ ojczyzną, a pobyt za granicą traktują w kategoriach tymczasowości, pewnej konieczności ekonomicznej. Tworzą zamknięte środowisko, ich funkcjonowanie właściwie jest ograniczone do pracy i starań o zaoszczędzenie pieniędzy, potrzeby towarzyskie zaspokajają podczas niedzielnego grillowania na wózku z supermarketu przed domem, unikają kontaktu z nową kulturą; świat, w którym przebywają, jest światem obcym, w pewnym sensie nieprzyjaznym, nie wiążą z nim przyszłości, odgrywają jedynie określoną rolę na rynku pracy, dlatego przekroczenie granicy kulturowo-społecznej ich nie obchodzi. Utrzymują stały kontakt z bliskimi w kraju, swoją odrębną tożsamość potwierdzają prostymi znakami - krajowym piwem i jedzeniem, muzyką z akcentami narodowymi czy nacjonalistycznymi, skojarzeniami z barwami narodowymi. „Codzienne flagowanie ojczyzny”, by posłużyć się określeniem Michaela Billiga ${ }^{13}$, w odczuwanych jako nieprzyjazne warunkach potwierdza obcość, ale jednocześnie stwarza poczucie bezpieczeństwa i przynależności. Dotyczy to głównie postaci mężczyzn, w przypadku których drugą, poza strategią zamknięcia i unikania konfrontacji, prezentowaną w tekście postawą jest podejście roszczeniowe, połączone z frustracją z powodu własnych niepowodzeń. Agresywna uwaga jednego z bohaterów: „Jak sobie nie poradzę, skoro z tym byle jaka tłusta Murzynka sobie radzi?!"14, oddaje nie tylko wrogi stosunek do innych, ale przede wszystkim poczucie wyższości, mimo braku określonych kompetencji, w tym wypadku - znajomości języka.

Trudności w podjęciu wyzwań nowego życia i zaakceptowaniu istniejących warunków przez mężczyzn można interpretować w kontekście zależności pomiędzy identyfikacjami genderowymi a procesami adaptacyjnymi. Jak stwierdza Tatiana Czerska, nawiązując do ustaleń Barbary Pasamonik, ,proces akulturacji przychodzi mężczyznom trudniej w związku z poczuciem niedowartościowania i utraty uprzywilejowanej pozycji w rodzinie i społeczeństwie. Tożsamość kobiet nie podlega takiemu uzależnieniu, co ułatwia im porzucenie starej i adaptację do nowej kultury" ${ }^{\prime 5}$. W tekście Kepplovej mężczyźni z zamkniętej enklawy migrantów, pozbawieni pozycji, do której w rodzimym, dosyć patriarchalnym środowisku byli przyzwyczajeni, którą traktowali, również nieświadomie, w kategoriach należnego im prawa, często unikają sytuacji wymagających podjęcia refleksji toż-

13 M. Billig, Banalny nacjonalizm, przeł. M. Sekerdej, Kraków 2008, s. 175 i nast.

14 Z. Kepplová, Buchty švabachom, Levice 2011, s. 23.

15 T. Czerska, Od zakorzenienia do nomadyzmu: doświadczenie migracji w kobiecych narracjach osobistych [w:] Narracje migracyjne w literaturze polskiej XX i XXI wieku, red. H. Gosk, Kraków 2012, s. 328-329. 
samościowej lub okazują zupełną bezradność i apatię, co zbliża ich do „atroficznego modelu mężczyzny", jak proponuje stan ten nazwać Ivica Hajdučeková ${ }^{16}$.

Gettoizacja i jej konsekwencje dotyczą w debiucie Kepplovej nielicznych, raczej drugoplanowych postaci, za dominującą w opisie doświadczeń migracyjnych sytuację podmiotu uznać należy stan zawieszenia, bycia ,pomiędzy” wyraźnymi wartościami identyfikacyjnymi. Konkretne reprezentacje tej sytuacji na płaszczyźnie kreacji bohaterów i ich reakcji na otaczającą rzeczywistość, poza wymienionymi powyżej, obejmują również: kompensacyjną ucieczkę w przypadkowe relacje seksualne, które dają chwilową ulgę oraz zastępują brakujące więzi i poczucie zakorzenienia; życiowe rozczarowania, wynikające z niewspółmierności oczekiwań i wyobrażeń dotyczących intymności, którą można thumaczyć między innymi odmiennym zapleczem kulturowym; próby unieważniania rodzimej specyfiki kulturowej, przy konsekwentnym dążeniu do włączenia się w ruch globalnego przepływu ludzi, wartości i dóbr konsumpcyjnych. Pomijając szczegółowe omówienie tych wątków, należy podkreślić element, który je łączy, mianowicie deziluzyjne rozumienie możliwości przekroczenia granic obcości, a tym samym stałe, choć w różnym stopniu manifestowane, poczucie bycia innym, zwykle gorszym i potencjalnie wykluczonym.

Pozycja wyjściowa przybyszów z Europy Środkowej do świata Europy Zachodniej naznaczona jest szeregiem wywołujących niechęć i frustrację problemów, zarówno praktycznych (problemy mieszkaniowe, konieczność podjęcia pracy poniżej kwalifikacji), jak i psychologiczno-emocjonalnych, związanych głównie z odczuwaną podrzędną pozycją społeczną i kulturową. Zupełnie inny status mają osoby, które przemieszczają się na tej samej linii, ale w odwrotnym kierunku. Ekspaci, delegowani przez duże firmy lub agencje, przybywają do nowego środowiska, w którym mają zapewnione dobre warunki mieszkaniowe i finansowe, wyjazd traktować mogą jako kolejny etap kariery, przy okazji oznacza on możliwość, czy raczej konieczność, zetknięcia się z egzotyczną, z ich perspektywy, kulturą. Kwestie odbioru środkowoeuropejskiej rzeczywistości przez przedstawicieli bogatszej części świata, która jest równocześnie postrzegana jako bardziej cywilizowana, w debiucie Kepplovej stanowią wątki raczej poboczne, warto im jednak poświęcić krótki komentarz. Zaprezentowani w jednym z fragmentów prozy obcokrajowcy - pracownicy filii międzynarodowej firmy w Budapeszcie - ostentacyjnie okazują poczucie wyższości, czy wręcz pogardę dla miejscowej kultury, zwyczajów, jedzenia, warunków życia, myślenia. Chociaż pobyt za granicą traktują jako tymczasowy i nie zamierzają tego miejsca realnie uznać za własne, gdziekolwiek się pojawiają, symbolicznie zawłaszczają przestrzeń, we wszelkich relacjach występują z pozycji dominacji ekonomicznej, społecznej i seksualnej. W swoim przekonaniu reprezentują ,prawdziwą kulturę”, a swój pogardliwy stosunek do ludzi, którzy są ,tylko wadliwymi kopiami starych Francuzów"17, rozumieją jako uzasadniony. Charakterystykę tę uzupełniają

16 I. Hajdučeková, I., Ženy o ženách (Rodový aspekt v súčasnej slovenskej literatúre) [w:] K poetologickým a axiologickým aspektom slovenskej literatúry po roku 2000, red. M. Součková, Prešov 2013, s. 175.

17 Z. Kepplová, Buchty..., s. 92. 
i pośrednio dopełniają nostalgiczne odwołania do kolonializmu oraz rasistowskie i ksenofobiczne komentarze. Ich postrzeganie miejscowej kultury jest, oczywiście, oparte na szeregu stereotypów, uprzedzeń, opozycji my-oni, z wyraźnie przypisanymi wartościami; staje się ono zresztą powodem niechęci pośrednio okazywanej im przez mieszkańców miasta. Kwestii stosunku ludzi Zachodu do środkowoeuropejskiej rzeczywistości słowacka pisarka więcej uwagi poświęca w kolejnej opublikowanej książce.

SLO_ODA (WOL_OŚĆ), pierwsza część drugiej pozycji Kepplovej, podobnie jak debiutancka proza, została podzielona na mniejsze fragmenty; tym razem są to stylizowane na wyznania monologi bohaterów, z wpisanym w ich strukturę odbiorcą, łączące w sobie elementy wspomnień, refleksji, opisów sytuacji. W kontekście prezentowanych rozważań najważniejszymi postaciami, jakie z tej fragmentarycznej narracji się wyłaniają, jest trójka przybyszów z USA, małżeństwo i lektor języka angielskiego, którzy w latach 90. XX wieku przyjeżdżają do Bratysławy. Miasto, podobnie jak różne sfery życia społecznego i indywidualnego jego mieszkańców, znajduje się w okresie przejściowym, w czasie odrzucania form związanych z okresem komunizmu i jednoczesnego wprowadzania, często w chaotyczny sposób, form kojarzonych z demokratycznym ładem, który stopniowo jest budowany.

W procesach zmian rolę odegrać ma właśnie młode małżeństwo, zwłaszcza mężczyzna, specjalista z zakresu gospodarki rynkowej. Ich wyjazd w kręgu rodzinnym traktowany jest w kategoriach misji, w dziwnym wschodnioeuropejskim kraju, gdzie ,śnieg, lód, zasypane drogi, ciągłe problemy z zaopatrzeniem. Wódka. Ludzie z zepsutymi zębami"18, mają być ,przedstawicielami amerykańskich idei”, którzy przybywają „,budować demokrację, nieść pochodnię wolności”19. Bohaterowie, choć początkowo wyjazd, uzasadniony pracą, postrzegają jako kolejną przygodę, zgodną z projektem ich życia jako ciągu niekonwencjonalnych, zaskakujących otoczenie działań, stopniowo misyjność swojego pobytu akceptują, co prowadzi do modelowej konfrontacji centrum i peryferii, przeprowadzanej zgodnie ze schematem kulturowego podboju: ,postaci z Zachodu są przedstawione jako kolonizatorzy, przybywający uczyć i wychowywać barbarzyńskich «tubylców» w zakresie różnego rodzaju wolności - wolności gospodarczej, ale też wolności realizowania swoich marzeń" ${ }^{20}$. Przyjętego planu zmiany różnicy w tożsamość, ,przebudowania kraju według własnych wyobrażeń”21, „wyprodukowania ludzi, to znaczy obywateli"’22, oczywiście, nie udaje się zrealizować, co wywołuje poczucie chaosu, objawia się zniechęceniem, smutkiem, atakami histerii. Bohaterowie znajdują się w sytuacji stykania się kultur i systemów wartości, ich doświadczenie w nowym otoczeniu to doświadczenie „między”, które Czapliński charakteryzuje następująco: „Szczególną cechą owego doświadczenia jest nałożenie się starej i nowej konwencji poznawczej; ich niekompatybilność

18 Z. Kepplová, 57 km od Taškentu, Levice 2013, s. 11.

19 Ibid., s. 15.

20 I. Taranenková, Prízrak slobody, realita beztiaže, „Romboid” 2014, nr 4, s. 10.

21 Z. Kepplová, 57 km..., s. 64.

22 Ibid., s. 49. 
prowadzi jednak nie do systemu nowego, stanowiącego syntezę obu, lecz raczej do systemów niekompletnych, półotwartych, niespójnych i hybrydycznych"23. Niespójności i hybrydyczności, charakterystycznych dla społeczeństw współczesnych $^{24}$, omawiane postaci nie chcą jednak zaakceptować, stąd niepokój, który tłumaczyć można również jako wyraz lęku przed refleksją nad własnymi uwarunkowaniami tożsamościowymi, uznawanymi i odczuwanymi jako atrakcyjniejsze i bardziej wartościowe. W kategoriach egzotyki Słowację postrzega również wspomniany lektor angielskiego, ma ona dla niego przede wszystkim walor obszaru jeszcze nieskażonego zjawiskami, które w swojej rodzimej kulturze odrzuca: kapitalizmu, komercjalizmu, konsumpcjonizmu. Ponownie mamy więc do czynienia z uproszczeniem, z którego bohater szybko zdaje sobie sprawę, a obserwując miejscową fascynację nowymi trendami - którą symbolizuje, wzbudzające entuzjazm i obszernie komentowane w prasie, otwarcie pierwszego punktu McDonald's - wyjeżdża do Indii. Wspomniani bohaterowie stopniowo „dojrzewają do uświadomienia sobie, że z taką przestrzenią nie zdołają się zespolić, wydaje się wręcz, jakby celowo stawiała im opór i próbowała ich z siebie "wyrzucić»" "25; zastana rzeczywistość jest dynamiczna i zmienna, wymyka się schematom i nie poddaje założonym planom jej kształtowania, co wywołuje poznawczy niepokój i rozczarowanie.

W odniesieniu do linii intymnej, obecnej w drugich częściach obydwu książek Kepplovej, za istotny w kontekście migracji i zagadnień tożsamościowych uznać należy problem poszukiwania nowych, w tym nieheteronormatywnych, relacji intymnych. Przedstawiane związki - miłosny trójkąt Słowaczki, Węgra i Rumunki, z wyeksponowanym wątkiem lesbijskim w debiucie i niezobowiązującą relację Serbki, Węgra i wychowanego w USA syna węgierskich emigrantów w prozie $57 \mathrm{~km}$ od Taškentu - interpretować można w perspektywie ustaleń dotyczących współczesnych otwartych form intymności, takich jak opisywana przez Anthony'ego Giddensa „czysta relacja”, która budowana jest dla niej samej, nie opiera się na kryteriach zewnętrznych wobec związku, a ,trwa tylko dotąd, dokąd obie strony czerpią z niej dość satysfakcji, by chcieć ją utrzymać" 26 . Znaczące jest, że intymne poszukiwania bohaterek usytuowane zostają w obcym mieście, co tym poszukiwaniom sprzyja, sprawia, że nawiązywanie relacji jest pozbawione istniejących prawdopodobnie w ich środowisku rodzimym ograniczeń. Migracja daje im możliwości nowego rozumienia i przeżywania sfery intymnej, podążania za własnymi potrzebami i dokonania pewnych przewartościowań w obszarze tożsamości seksualnej. Płynność relacji, ich otwarty charakter stają się odkrywaną przez bohaterki wartością, chociaż same związki mogą wywoływać również

23 P. Czapliński, op. cit., s. 33.

24 „Hybrydyczność nie jest wyłączną tożsamością imigranta, lecz stanem, w jakim znajdują się wszystkie dzisiejsze społeczeństwa. Wyartykułuje to jednak dopiero ten, kto niespójności kulturowe uzna za własne". - ibid., s. 34.

25 L. Szentesiová, Malá t’ažkopádna nostalgia, „Romboid” 2014, nr 4, s. 10.

26 A. Giddens, Przemiany intymności. Seksualność, miłość i erotyzm we współczesnych społeczeństwach, przeł. A. Szulżycka, Warszawa 2006, s. 75. 
uczucie niepewności. Ten krąg problemowy prozy słowackiej autorki, z konieczności zarysowany bardzo szkicowo, wymagałby odrębnej interpretacji.

Bohaterki i bohaterowie Kepplovej to w większości postaci wieloimienne i wielojęzyczne, co nie oznacza jedynie używania przez niektórych z nich różnych form imienia (Michal w Helsinkach to Mika, a Béla w swoim międzynarodowym towarzystwie jest Billem) czy posługiwania się, zależnie od sytuacji, różnymi językami. Wiąże się raczej z pozostawaniem pomiędzy terytoriami, kulturami, identyfikacjami społecznymi, co pokazuje, że tradycyjna alternatywa w ujmowaniu doświadczeń migracyjnych - pełna asymilacja lub zamknięcie się w hermetycznej diasporze - nie wyczerpuje możliwości ich opisu ${ }^{27}$. Do kultury miejscowej się zbliżają, przyswajają jej niektóre elementy, jednocześnie zachowując niektóre znaki identyfikacyjne kultury rodzimej, pozostają w ,,przestrzeni niejasnego oddzielenia, w której jakości ulegają stłoczeniu, przemieszaniu i aglomeracji"28. Ich tożsamość ma charakter procesualny, płynny, hybrydyczny, dodać przy tym warto, że niestabilna pozycja niedookreślenia i zawieszenia wywołuje raczej stany niepokoju niż euforii związanej z wolnością, możliwościami wyboru itd. ${ }^{29}$, które zreszta w praktyce są w znacznym stopniu ograniczone. Dotyczy to, jak powyżej zaznaczono, większości bohaterów, konkretnie - mieszkańców Europy Środkowej, wchodzących w interakcje z inną kulturą; dla prezentowanych w tekstach przybyszów z Zachodu kwestia niespójności nie wydaje się takim problemem.

Pojęcie hybrydyczności, zgodnie z sugestią Czaplińskiego („literatura migracyjna «wybiera» hybrydyczność" ${ }^{30}$ ), odnieść można nie tylko do zagadnień współczesnej, płynnej kultury i niestabilnej tożsamości jednostki, można je także wykorzystać w znaczeniu literaturoznawczym. Strategia łączenia różnych konwencji i form, oscylowanie między nimi, bez dążenia do wyraźnej syntezy i spójności, w tekstach Kepplovej jest wyraźnie dostrzegalna, na co zwracano uwagę zarówno neutralnie: „Uniwersum Kepplovej zbudowane jest z różnych perspektyw, form, gatunków” ${ }^{31}$, jak i krytycznie: ,postrzeganie świata przez autorkę bliższe jest publicystyce reportażowej niż literaturze" 32 . Sama pisarka natomiast przyznaje: „Interesuje mnie pisanie na pograniczu reportażu/teorii/bele-

27 M. Dajnowski, Migracje terytorialne i tekstualne - rekonesans, „Białostockie Studia Literaturoznawcze" $2014 \mathrm{nr} 5$, s. 283.

28 P. Czapliński, op. cit., s. 33.

${ }^{29}$ Na płaszczyźnie ogólniejszej stany te można interpretować w kontekście charakterystyki kondycji człowieka współczesnego, sytuacja migracji uwypuklałaby niektóre jej aspekty, m.in. te, na które zwraca uwagę Zygmunt Bauman: „Fragmentacja, epizodyczność i wieloznaczność życia mają swoje strony przyjemne: przynoszą one być może mylące, ale błogie poczucie wolności, nieskrępowania, szans nigdy niewyczerpanych, nieostateczności żadnej z klęsk i obfitości niewypróbowanych jeszcze przyszłych rozkoszy. Ale ma też aspekty dręczące i ponure. (...) Sygnały są sprzeczne i wprawiające w zamęt. Marzy się więc świat prostszy, bardziej jednoznaczny, dający się ogarnąć jednym spojrzeniem i wymierzyć jedną miarką. Tęsknota za «wielkim uproszczeniem» jest typowo ponowoczesną wersją znanej od wieków melancholii, ponowoczesnym wydaniem romantycznego ennui"'. Z. Bauman, Dwa szkice o moralności ponowoczesnej, Warszawa 1994, s. 38-39.

30 P. Czapliński, op. cit., s. 26.

31 L. Macsaliová, Eva v krajine zázrakov, https://kultura.pravda.sk/kniha/clanok/399422-kniha-tyzdna-eva-v-krajine-zazrakov/ (dostęp: 10.11.2018).

32 L. Szentesiová, op. cit., s. 12. 
trystyki, zamienne wykorzystywanie tych gatunków i badanie przepuszczalności ich granic" "33. Rozumiana w taki sposób hybrydyczność poetyki, poszukiwanie i pozostawanie „,W cyklicznych wahaniach przynależności i zerwania" ${ }^{34}$ koresponduje z opisywanymi doświadczeniami i niedookreślonymi kształtami współczesnych tożsamości.

Nurt najnowszej prozy słowackiej dotyczącej migracji, mimo wyrażanych przez niektórych krytyków wątpliwości, czy „historie «nowoczesnych włóczęgów» powoli się nie wyczerpały"35, nadal się rozwija. Wydaje się, ze jego potencjał tkwi w poszerzeniu pola tematycznego o kolejne problemy, między innymi tworzenie nowych wspólnot, procesy osłabiania identyfikacji narodowych, ale też wzmacniania ich form radykalnych, konieczność konfrontacji ze zjawiskiem uchodźstwa. Można przypuszczać, że równolegle do powstawania nowych tekstów będą się kształtować i stopniowo stabilizować także kategorie badawcze, w jakich można je ujmować i opisywać.

\section{Bibliografia}

Barborík V., Ja: jedna (jediná?) podoba súcasnej prózy (Kepllová - Kopcsay Modrovich-Rosová), „Romboid” 2012, nr 7, s. 50-55.

Bauman Z., Dwa szkice o moralności ponowoczesnej, Warszawa 1994.

Billig M., Banalny nacjonalizm, przeł. M. Sekerdej, Kraków 2008.

Csiba K., Passia R., Taranenková I., Próza [w:] Hladanie súčasnosti. Slovenská literatúra začiatku 21. storočia, red. R. Passia, I. Taranenková, Bratislava 2014, s. $37-109$.

Czapliński P., Kontury mobilności [w:] Poetyka migracji. Doświadczenie granic w literaturze polskiej przełomu XX i XXI wieku, red. P. Czapliński, R. Makarska, M. Tomczok, Katowice 2013, s. 9-42.

Czerska T., Od zakorzenienia do nomadyzmu: doświadczenie migracji w kobiecych narracjach osobistych [w:] Narracje migracyjne w literaturze polskiej XX i XXI wieku, red. H. Gosk, Kraków 2012, s. 321-335.

Dajnowski M., Migracje terytorialne i tekstualne - rekonesans, „Białostockie Studia Literaturoznawcze" 2014, nr 5, s. 279-290.

Fiut A., Być (albo nie być) Środkowoeuropejczykiem, Kraków 1999.

Giddens A., Przemiany intymności. Seksualność, miłość i erotyzm we współczesnych społeczeństwach, przeł. A. Szulżycka, Warszawa 2006.

Gosk H., Wprowadzenie [w:] Narracje migracyjne w literaturze polskiej XX i XXI wieku, red. H. Gosk, Kraków 2012, s. 7-11.

Hajdučeková I., Ženy o ženách (Rodový aspekt v súčasnej slovenskej literatúre) [w:] K poetologickým a axiologickým aspektom slovenskej literatúry po roku 2000, red. M. Součková, Prešov 2013, s. 172-183.

Kepplová Z., 57 km od Taškentu, Levice 2013.

33 M. Mikšík, Druhá... 57 km od Taškentu, http://www.litcentrum.sk/rozhovory/druha-57-km-od-taskentu (dostęp: 10.11.2018).

34 M. Dajnowski, op. cit., 283.

35 L. Szentesiová, op. cit., s. 12. 
Kepplová Z., Buchty švabachom, Levice 2011.

Macsaliová, L., Eva vkrajinezázrakov, https://kultura.pravda.sk/kniha/clanok/399422kniha-tyzdna-eva-v-krajine-zazrakov/ (dostęp: 10.11.2018).

Mikšík M., Druhá... 57 km od Taškentu, http://www.litcentrum.sk/rozhovory/druha-57-km-od-taskentu (dostęp: 10.11.2018).

Nycz R., Kultura jako czasownik. Sondowanie nowej humanistyki, Warszawa 2017.

Passia R., Skúsenost’s iným, „Romboid” 2011, nr 9-10-11, s. 13-16.

Prušková Z., Stratení v príbehoch, vynájdení v jazyku, „Romboid” 2011, nr 9-10-11, s. $13-16$.

Szentesiová L., Malá t’ažkopádna nostalgia, „Romboid” 2014, nr 4, s. 9-12.

Taranenková I., Prízrak slobody, realita beztiaže, „Romboid” 2014, nr 4, s. 9-12. 